\title{
Role of $\mathrm{IP}_{3}$ in modulation of spontaneous activity in pacemaker cells of rabbit urethra \\ G. P. Sergeant, M. A. Hollywood, K. D. McCloskey, N. G. McHale and K. D. Thornbury \\ Am J Physiol Cell Physiol 280:C1349-C1356, 2001.
}

You might find this additional info useful...

This article cites 32 articles, 16 of which can be accessed free at:

http://ajpcell.physiology.org/content/280/5/C1349.full.html\#ref-list-1

This article has been cited by 22 other HighWire hosted articles, the first 5 are:

Sarcoplasmic Reticulum Function in Smooth Muscle

Susan Wray and Theodor Burdyga

Physiol Rev, January , 2010; 90 (1): 113-178.

[Abstract] [Full Text] [PDF]

Caffeine inhibits nonselective cationic currents in interstitial cells of Cajal from the murine jejunum

Nan Ge Jin, Sang Don Koh and Kenton M. Sanders

Am J Physiol Cell Physiol, October , 2009; 297 (4): C971-C978.

[Abstract] [Full Text] [PDF]

Role of mitochondria in modulation of spontaneous $\mathrm{Ca}^{2+}$ waves in freshly dispersed interstitial cells of Cajal from the rabbit urethra

Gerard P. Sergeant, Eamonn Bradley, Keith D. Thornbury, Noel G. McHale and Mark A.

Hollywood

J Physiol, October 1, 2008; 586 (19): 4631-4642.

[Abstract] [Full Text] [PDF]

Properties of spontaneous $\mathrm{Ca}^{2+}$ transients recorded from interstitial cells of Cajal-like cells of the rabbit urethra in situ

Hikaru Hashitani and Hikaru Suzuki

J Physiol, September 1, 2007; 583 (2): 505-519.

[Abstract] [Full Text] [PDF]

$\mathrm{Ca}^{2+}$ signalling in urethral interstitial cells of Cajal

Gerard P. Sergeant, M. A. Hollywood, N. G. McHale and K. D. Thornbury

J Physiol, November 1, 2006; 576 (3): 715-720.

[Abstract] [Full Text] [PDF]

Updated information and services including high resolution figures, can be found at:

http://ajpcell.physiology.org/content/280/5/C1349.full.html

Additional material and information about AJP - Cell Physiology can be found at:

http://www.the-aps.org/publications/ajpcell

This infomation is current as of March 8, 2012.

AJP - Cell Physiology is dedicated to innovative approaches to the study of cell and molecular physiology. It is published 12 times a year (monthly) by the American Physiological Society, 9650 Rockville Pike, Bethesda MD 20814-3991. Copyright @ 2001 by the American Physiological Society. ISSN: 0363-6143, ESSN: 1522-1563. Visit our website at http://www.the-aps.org/. 


\title{
rapid communication
}

\section{Role of $\mathrm{IP}_{3}$ in modulation of spontaneous activity in pacemaker cells of rabbit urethra}

\author{
G. P. SERGEANT, M. A. HOLLYWOOD, K. D. McCLOSKEY, \\ N. G. MCHALE, AND K. D. THORNBURY \\ Smooth Muscle Group, Department of Physiology, The Queen's University \\ of Belfast, Belfast BT9 7BL, Northern Ireland, United Kingdom
}

Received 19 May 2000; accepted in final form 10 December 2000

Sergeant, G. P., M. A. Hollywood, K. D. McCloskey, N. G. McHale, and K. D. Thornbury. Role of $\mathrm{IP}_{3}$ in modulation of spontaneous activity in pacemaker cells of rabbit urethra. Am J Physiol Cell Physiol 280: C1349-C1356, 2001.-Isolated interstitial ("pacemaker") cells from rabbit urethra were examined using the perforated-patch technique. Under voltage clamp at $-60 \mathrm{mV}$, these cells fired large spontaneous transient inward currents (STICs), averaging $-860 \mathrm{pA}$ and $>1 \mathrm{~s}$ in duration, which could account for urethral pacemaker activity. Spontaneous transient outward currents (STOCs) were also observed and fell into two categories, "fast" (<100 ms in duration) and "slow" (>1 s in duration). The latter were coupled to STICs, suggesting that they shared the same mechanism, while the former occurred independently at faster rates. All of these currents were abolished by cyclopiazonic acid, caffeine, or ryanodine, suggesting that they were activated by $\mathrm{Ca}^{2+}$ release. When D-myo-inositol 1,4,5-trisphosphate $\left(\mathrm{IP}_{3}\right)$-sensitive stores were blocked with 2-aminoethoxydiphenyl borate, the STICs and slow STOCs were abolished, but the fast STOCs remained. In contrast, the fast STOCs were more nifedipine sensitive than the STICs or the slow STOCs. These results suggest that while fast STOCs are mediated by a mechanism similar to STOCs in smooth muscle, STICs and slow STOCs are driven by $\mathrm{IP}_{3}$. These results support the hypothesis that pacemaker activity in the urethra is driven by the $\mathrm{IP}_{3}$-sensitive store.

D-myo-inositol 1,4,5-trisphosphate; spontaneous transient inward currents; spontaneous transient outward currents

INTRACELLULAR RECORDINGS from the urethra reveal that it generates spontaneous electrical slow waves $(9,10)$ that are thought to be due to summation of smaller electrical events called spontaneous transient depolarizations (STDs). The currents (spontaneous transient inward currents, STICs), which underlie the STDs, are believed to result from activation of $\mathrm{Ca}^{2+}$-dependent

Address for reprint requests and other correspondence: K. D. Thornbury, Smooth Muscle Group, Dept. of Physiology, The Queen's Univ. of Belfast, 97 Lisburn Road, Belfast BT9 7BL, Northern Ireland, United Kingdom (E-mail: k.thornbury@qub.ac.uk).
$\mathrm{Cl}^{-}$channels by $\mathrm{Ca}^{2+}$ released from intracellular stores $(9,10,21)$. At present, it is unclear whether the $\mathrm{Ca}^{2+}$ that drives this mechanism is released via D-myoinositol 1,4,5-trisphosphate $\left(\mathrm{IP}_{3}\right)$ - or ryanodine-sensitive stores. In smooth muscle cells, STICs appear to be activated the same way as STOCs (spontaneous transient outward currents), via ryanodine-sensitive $\mathrm{Ca}^{2+}$ release channels $(3,14,32)$. However, several intracellular microelectrode studies in the gut $(22,29)$, where a pacemaker mechanism similar to the urethra has been proposed $(22,29)$, suggest that the $\mathrm{Ca}^{2+}$ is released by $\mathrm{IP}_{3}$. The only way to resolve this issue would be to study the mechanisms underlying STICs and STOCs in the pacemaker cells themselves, where it is conceivable that the $\mathrm{Ca}^{2+}$-activated $\mathrm{Cl}^{-}$and $\mathrm{K}^{+}$channels are activated by different mechanisms.

We have recently isolated cells from rabbit urethra (26) that resemble the interstitial cells of Cajal (ICC) in the gut, where they are widely believed to be the pacemakers $(13,20,22)$. These urethral "interstitial cells" differed significantly, both in their morphological and electrophysiological properties, from smooth muscle cells isolated from the same preparation. They expressed large $\mathrm{Ca}^{2+}$-activated $\mathrm{Cl}^{-}$currents and generated STICs and STDs, while in contrast, the smooth muscle cells expressed little $\mathrm{Cl}^{-}$current and were electrically quiescent. These properties, together with their resemblance to the gastrointestinal ICCs, make the urethral interstitial cells likely candidates to fulfill the role of pacemakers (26). In the present study, we have investigated the mechanisms activating STICs and STOCs in these cells and have found evidence for differential regulation of these currents. Specifically, $\mathrm{IP}_{3}$ appears to drive the pacemaker mechanism, while STOCs continue to fire when $\mathrm{IP}_{3}$-induced $\mathrm{Ca}^{2+}$ release is blocked.

\footnotetext{
The costs of publication of this article were defrayed in part by the payment of page charges. The article must therefore be hereby marked "advertisement" in accordance with 18 U.S.C. Section 1734 solely to indicate this fact.
} 


\section{METHODS}

Bladder and urethra were removed from both male and female rabbits immediately after they had been killed by lethal injection of pentobarbitone. The most proximal $1 \mathrm{~cm}$ of the urethra was removed and placed in Krebs solution, and from this, strips were dissected for cell dispersal.

For cell dispersal, 0.5-cm strips of proximal urethra were cut into $1-\mathrm{mm}^{3}$ pieces and stored in Hanks' $\mathrm{Ca}^{2+}$-free solution for $30 \mathrm{~min}$ before being incubated in an enzyme medium containing (per $5 \mathrm{ml}$ of Hanks' $\mathrm{Ca}^{2+}$-free solution) $15 \mathrm{mg}$ of collagenase (Sigma, type 1A), $1 \mathrm{mg}$ of protease (Sigma, type XXIV), $10 \mathrm{mg}$ of BSA (Sigma), and $10 \mathrm{mg}$ of trypsin inhibitor (Sigma) for $\sim 5$ min at $37^{\circ} \mathrm{C}$. They were then placed in Hanks' $\mathrm{Ca}^{2+}$-free solution and stirred for another 5-10 min to release both single relaxed smooth muscle cells and interstitial cells. These were placed in petri dishes containing Hanks' solution $\left(100 \mu \mathrm{M} \mathrm{Ca}^{2+}\right)$ and stored at $4^{\circ} \mathrm{C}$ for use within $8 \mathrm{~h}$.

Recordings were made using the amphotericin $\mathrm{B}$ perforated-patch method (25). After gigaseals were obtained, the series resistance fell over a 10- to 15-min period to $10-15 \mathrm{M} \Omega$ and remained stable for up to $1 \mathrm{~h}$. Voltage-clamp commands were delivered with an Axopatch 1D patch-clamp amplifier (Axon Instruments), and currents were recorded with a 12bit analog-to-digital/digital-to-analog converter (Labmaster; Scientific Solutions) interfaced to an Intel computer running pCLAMP software (Axon Instruments). During experiments, the dish containing the cells was superfused with physiological salt solution (PSS; solution 2). In addition, the cell under study was continuously superfused with PSS by means of a close delivery system consisting of a pipette (tip diameter 200 $\mu \mathrm{m})$ placed $\sim 300 \mu \mathrm{m}$ away. This could be switched, with a dead-space time of around $10 \mathrm{~s}$, to a solution containing a drug. All experiments were carried out at $37^{\circ} \mathrm{C}$.

The solutions used were of the following composition (in mM) 1) Hanks' $\mathrm{Ca}^{2+}$-free solution: $141 \mathrm{Na}^{+}, 5.8 \mathrm{~K}^{+}, 130.3$ $\mathrm{Cl}^{-}, 15.5 \mathrm{HCO}_{3}^{-}, 0.34 \mathrm{HPO}_{4}^{2-}, 0.44 \mathrm{H}_{2} \mathrm{PO}_{4}^{-}, 10$ dextrose, 2.9 sucrose, and 10 HEPES, pH adjusted to 7.4 with $\mathrm{NaOH} ; 2$ ) PSS: $130 \mathrm{Na}^{+}, 5.8 \mathrm{~K}^{+}, 135 \mathrm{Cl}^{-}, 4.16 \mathrm{HCO}_{3}^{-}, 0.34 \mathrm{HPO}_{4}^{2-}$,
$0.44 \mathrm{H}_{2} \mathrm{PO}_{4}^{-}, 1.8 \mathrm{Ca}^{2+}, 0.9 \mathrm{Mg}^{2+}, 0.4 \mathrm{SO}_{4}^{2-}, 10$ dextrose, 2.9 sucrose, and 10 HEPES, pH adjusted to 7.4 with $\mathrm{NaOH} ; 3$ ) $\mathrm{Cs}^{+}$pipette solution: $133 \mathrm{Cs}^{+}, 1 \mathrm{Mg}^{2+}, 135 \mathrm{Cl}^{-}, 0.5$ EGTA, and 10 HEPES, $\mathrm{pH}$ adjusted to 7.2 with $\mathrm{CsOH}$; and 4) $\mathrm{K}^{+}$ pipette solution: $133 \mathrm{~K}^{+}, 1 \mathrm{Mg}^{2+}, 135 \mathrm{Cl}^{-}, 0.5 \mathrm{EGTA}$, and 10 HEPES, $\mathrm{pH}$ adjusted to 7.2 with $\mathrm{KOH}$. In current clamp experiments, $80 \mathrm{mM}$ of the $\mathrm{KCl}$ was replaced with potassium gluconate to set the $\mathrm{Cl}^{-}$equilibrium potential to the more physiological value of $-24 \mathrm{mV}$.

The following drugs were used: caffeine, 2-nitro-4-carboxyphenyl $N, N$-diphenylcarbamate (NCDC), penitrem A, ryanodine, xestospongin C (all Sigma), 2-aminoethoxydiphenyl borate (2APB; Acros), cyclopiazonic acid (CPA; Calbiochem), and nifedipine (Bayer). Data is presented as means $\pm \mathrm{SE}$, and statistical differences were compared using Student's paired $t$-test, taking the $P<0.05$ level as significant.

\section{RESULTS}

Under control conditions, $>90 \%$ of interstitial cells fired regular STICs and STOCs when held under voltage-clamp conditions using the perforated-patch technique. Figure $1 A$ shows a typical recording from a cell held at $-30 \mathrm{mV}$ in which both STICs and STOCs may be observed during the control period. Addition of penitrem $\mathrm{A}$, a potent blocker of large conductance $\mathrm{Ca}^{2+}$ activated $\mathrm{K}^{+}$channels (BK channels) (18), completely blocked the STOCs over a period of $\sim 1 \mathrm{~min}$, similar to its action on single BK channels in urethral smooth muscle cells (12). It also unmasked larger STICs, suggesting that BK channels were activated during the STICs, partly offsetting them. Fig. $1, B$ and $C$, are expanded records of the activity of the periods marked $\mathrm{B}$ (control) and $\mathrm{C}$ (penitrem $\mathrm{A}$ ) in Fig. 1A. In Fig. $1 B$, it can be seen that the STICs had a duration in the order of seconds, while the STOCs fell into two broad types, those of small amplitude and short duration $(<100 \mathrm{~ms})$

Penitrem A

Fig. 1. Spontaneous transient inward currents (STICs) and spontaneous transient outward currents (STOCs) in an interstitial cell from rabbit urethra held at -30 $\mathrm{mV}$. A: recording over a 5 -min period where the effect of penitrem $\mathrm{A}(0.1 \mu \mathrm{M})$ was studied. Recording was continuous, except for 5 -s gaps between records. $B$ : record from the control period in $A$ was expanded to show the relationship between STICs, fast STOCs, and slow STOCs. $C$ : record from $A$ in the presence of penitrem A. This drug completely blocked the STOCs to unmask the true amplitude and time course of the STICs.

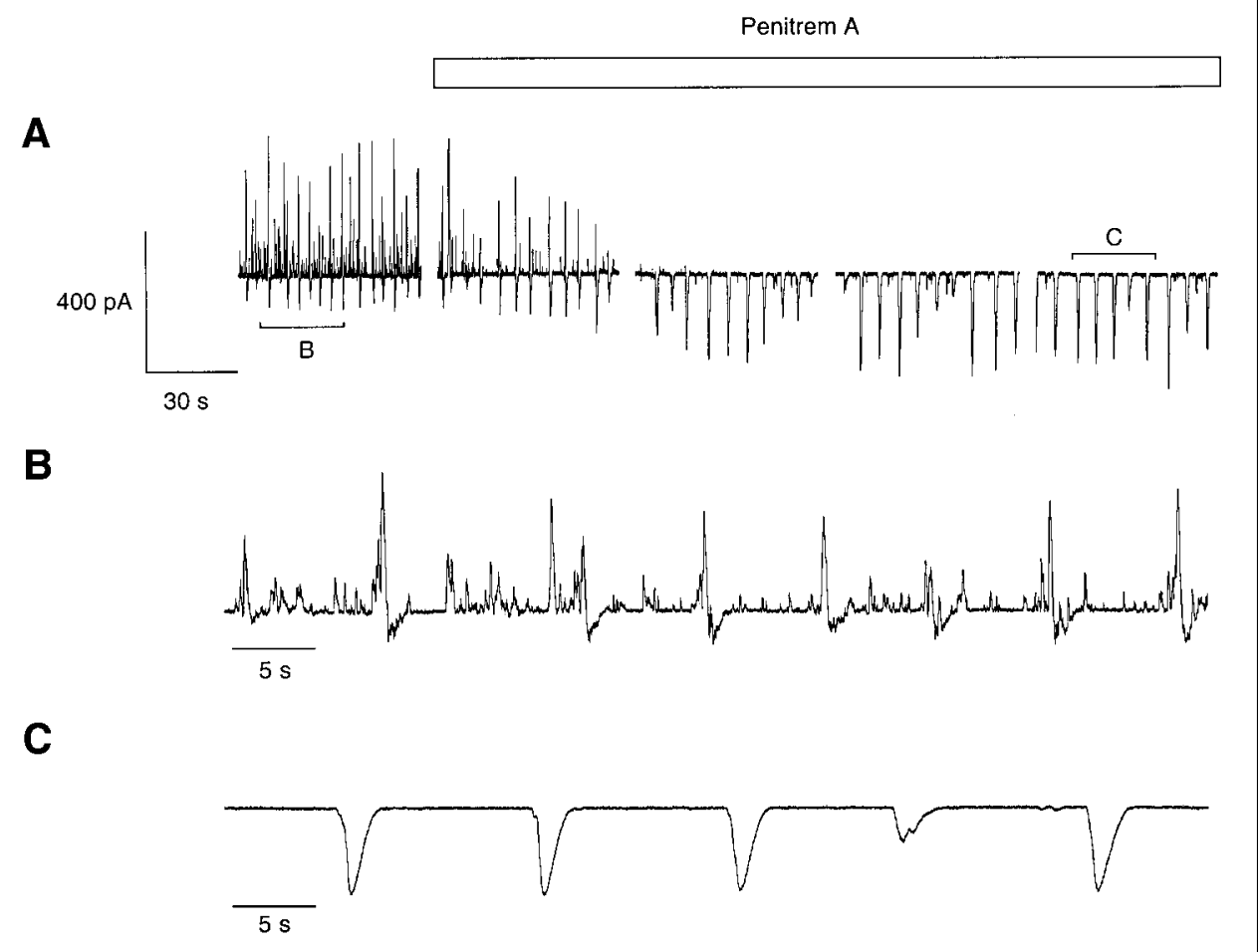


A

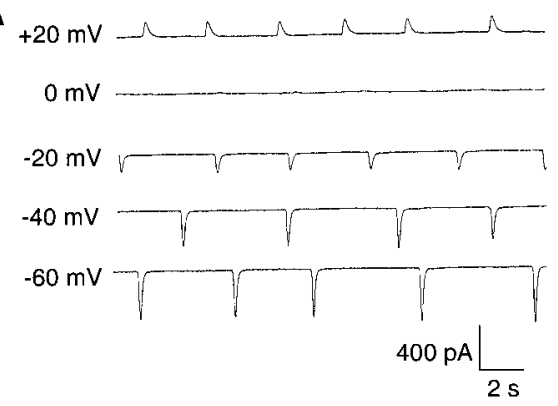

B

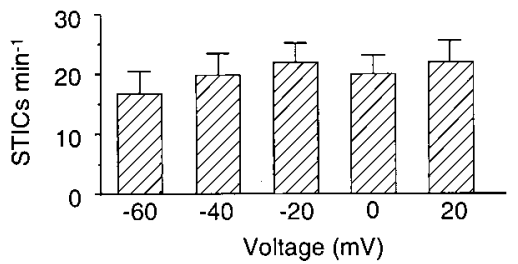

Fig. 2. STIC frequency is not dependent on membrane potential. $A$ : spontaneous currents recorded with a $\mathrm{Cs}^{+}$pipette in a cell held at various potentials. The currents reversed at $0 \mathrm{mV}$, as expected for a $\mathrm{Cl}^{-}$conductance, but their frequency varied little with voltage. $B$ : a summary for 8 cells in which STIC frequency was plotted against voltage.

and those of larger amplitude and longer duration. While the smaller fast STOCs bore no obvious relationship to the STICs, the slow STOCs were usually coupled to STICs (Fig. 1B), making it difficult to analyze their time course accurately at this potential. Therefore, we also studied them at $0 \mathrm{mV}$, which was the calculated $\mathrm{Cl}^{-}$equilibrium potential, $E_{\mathrm{Cl}}$ (Fig. 8). In nine cells studied at $0 \mathrm{mV}$, the mean amplitude of the slow STOCs was $343 \pm 89 \mathrm{pA}$, while their mean duration was $1,087 \pm 138 \mathrm{~ms}$. The latter was similar to the duration of STICs studied with $\mathrm{Cs}^{+}$pipettes $(1,156 \pm$ $120 \mathrm{~ms}$ at $-60 \mathrm{mV}$ and $1,206 \pm 117 \mathrm{~ms}$ at $-20 \mathrm{mV} ; n=$ 10 cells). The mean STIC amplitude was $-860 \pm 200$ $\mathrm{pA}$ at $-60 \mathrm{mV}$ and $-311 \pm 74 \mathrm{pA}$ at $-20 \mathrm{mV}\left(\mathrm{Cs}^{+}\right.$ pipettes; $n=10$ cells). Figure $1 C$ shows that when the BK channels were blocked, only STICs remained. We have previously demonstrated that these currents are mediated by $\mathrm{Ca}^{2+}$-activated $\mathrm{Cl}^{-}$channels (26).

We also studied STICs and STOCs at more hyperpolarized membrane potentials than $-30 \mathrm{mV}$. When cells were held at $-60 \mathrm{mV}$ (close to the resting potential of rabbit urethra) (11), we never observed STOCs, but STICs were present in $\sim 90 \%$ of cells (26). As cells were depolarized to -50 or $-40 \mathrm{mV}$, generally fast STOCs appeared, and at $-30 \mathrm{mV}$, slow STOCs similar to those in Fig. 1 were also present. The effect of depolarization on the frequency of fast STOCs was measured in four cells in which the values were $0 \pm 0 \mathrm{~min}^{-1}$ at $-60 \mathrm{mV}$, $162 \pm 104 \mathrm{~min}^{-1}$ at $-40 \mathrm{mV}, 251 \pm 139 \mathrm{~min}^{-1}$ at -20 $\mathrm{mV}$, and $262 \pm 101 \mathrm{~min}^{-1}$ at $0 \mathrm{mV}$.

Figure 2 shows the effect of changing the membrane potential on STIC frequency using $\mathrm{Cs}^{+}$pipette solution to block the BK channels that mediate STOCs. Perhaps surprisingly, the frequency of STICs was found to be little affected by membrane depolarization. Figure $2 A$ shows a cell in which STICs were studied at potentials ranging from -60 to $+20 \mathrm{mV}$. At $0 \mathrm{mV}\left(E_{\mathrm{Cl}}\right)$ they almost disappeared, while at $+20 \mathrm{mV}$ they had reversed to become outward currents. It is clear that frequency was little changed throughout this range of depolarization. This was confirmed in the summary data from eight cells shown in Fig. $2 B$ where, although there was a slight trend for frequency to increase on depolarization from -60 to $-20 \mathrm{mV}$, the effect was not significant $(P>0.05)$. Under current clamp conditions, these cells fire STDs mediated by the STICs (26). To assess the effect of membrane potential on this activity, STDs were examined using a $\mathrm{K}^{+}$pipette with $E_{\mathrm{Cl}}$ set to the more physiological value of $-24 \mathrm{mV}$. Figure 3 shows an example of a cell firing STDs at a rate of 6 $\min ^{-1}$ at rest. These reached a value close to the calculated $E_{\mathrm{Cl}}$. When the membrane was depolarized to $-40 \mathrm{mV}$, by injecting current, both the frequency of the STDs and the level to which they depolarized remained the same. Changing the membrane potential back to $-60 \mathrm{mV}$ and then $-80 \mathrm{mV}$ also failed to affect either frequency or the maximum depolarization of the STDs. When the cell was depolarized to $-20 \mathrm{mV}$, the STDs disappeared and were replaced by a mixture of fast and slower hyperpolarizations (Fig. 3, right).

The effect of caffeine $(10 \mathrm{mM})$ was to completely block STICs and STOCs. An example of the effect on STOCs (recorded at $0 \mathrm{mV}=E_{\mathrm{Cl}}$ ) is shown in Fig. $4 A$, where caffeine initially evoked a transient outward current after which STOCs were suppressed. These then gradually returned after washout of the drug. This result was confirmed in a total of four cells in which the STOCs were abolished. The effect of caffeine on STICs was similar in that it first evoked a transient inward current followed by abolition of the STICs (Fig. $4 B$ ). This was confirmed in eight cells firing STICs at a rate of $13 \pm 4 \mathrm{~min}^{-1}$ in which the effect of caffeine was to stop activity, which then returned to $12 \pm 4 \mathrm{~min}^{-1}$ after washout. These results are consistent with an

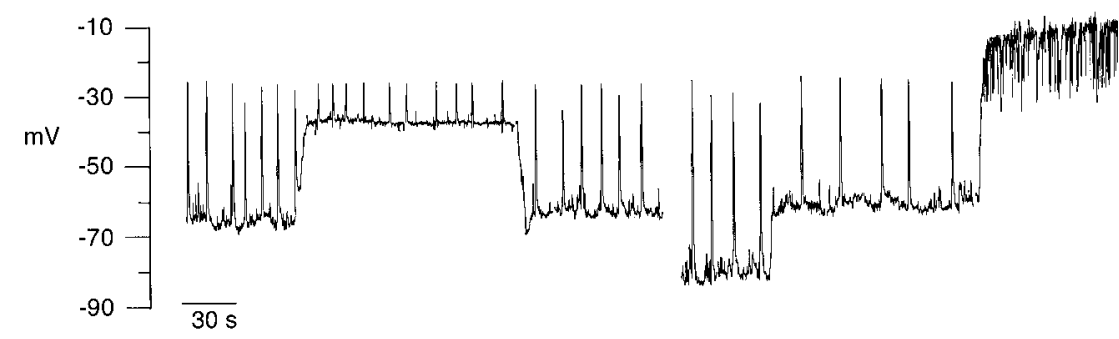

Fig. 3. Frequency of spontaneous depolarizations is not dependent on membrane potential. The trace shows a current clamp record from a cell recorded with $\mathrm{K}^{+}$pipette solution $\left[\mathrm{Cl}^{-}\right.$equilibrium potential $\left(E_{\mathrm{Cl}}\right)$ set to $-24 \mathrm{mV}$. Membrane potential was altered by injecting currents. 
A

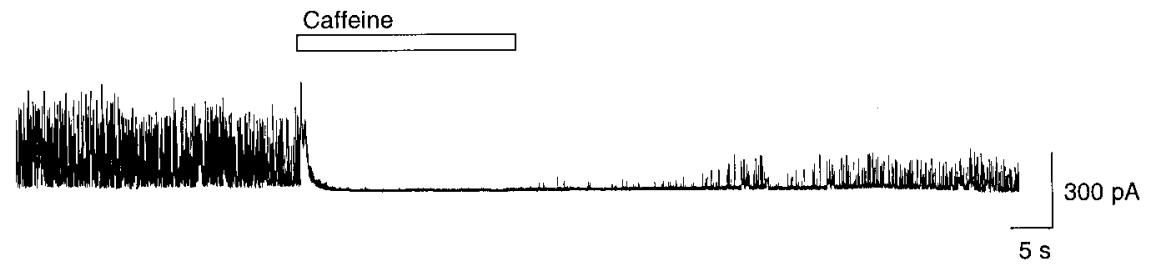

Fig. 4. Caffeine abolishes STICs and STOCs. A: STOCs from a cell held at $0 \mathrm{mV}$ using $\mathrm{K}^{+}$pipette solution $\left(E_{\mathrm{Cl}}\right.$ set to $\left.0 \mathrm{mV}\right)$. Caffeine $(10 \mathrm{mM})$ evoked a large transient outward current before abolishing the STOCs. B: STICs from a cell held at -60 $\mathrm{mV}$ using $\mathrm{Cs}^{+}$-rich solution. Caffeine (10 $\mathrm{mM}$ ) reversibly abolished the STICs.

B

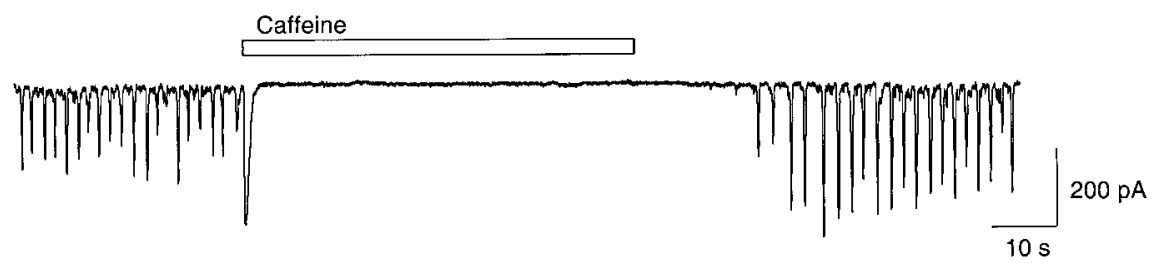

effect of caffeine dumping intracellular stores and suggest that stores are essential for firing STICs and STOCs. This was further supported by demonstrating that ryanodine $(30 \mu \mathrm{M})$ irreversibly abolished STICs in five cells (Fig. $5 A$ ), fast STOCs in four cells (Fig. $5 B$ ), and slow STOCs in four cells (Fig. $5 C$ ). In Fig. 5, $B$ and $C$, ryanodine transiently enhanced the amplitude of the STOCs before suppressing them, possibly by opening ryanodine-sensitive channels before blocking them. CPA also blocked STICs and STOCs, as shown in Fig. $5, D$ and $E$.

To investigate the possible role of $\mathrm{IP}_{3}$ in mediating STICs, we examined the action of xestospongin $\mathrm{C}$ (1 $\mu \mathrm{M})$, a drug reported to be a membrane-permeant blocker of $\mathrm{IP}_{3}$ receptors (7). Although its effect was to reduce STIC amplitude by $90 \%(n=6)$, it also evoked a large inward current, suggesting that it released intracellular $\mathrm{Ca}^{2+}$, as suggested by Broad et al. (4). Therefore, we did not pursue this substance further. However, two other substances known to interfere with $\mathrm{IP}_{3}$-mediated responses were found to block STICs. An example of the effect of $100 \mu \mathrm{M}$ NCDC, a blocker of phospholipase C, is shown in Fig. 6 in which it reversibly blocked the STICs 3 min after it was applied. In six cells, NCDC reduced STIC frequency from $14 \pm 3$ to $3 \pm 2 \mathrm{~min}^{-1}$. The second drug, 2APB, has recently been described as a specific blocker of the $\mathrm{Ca}^{2+}$-release channels coupled to $\mathrm{IP}_{3}$ receptors (23). Before its effects on STICs and STOCs were tested, a set of control experiments were performed on norepinephrine- and caffeine-evoked $\mathrm{Cl}^{-}$currents to test its specificity. Figure $7 \mathrm{~A}$ shows that norepinephrine evoked a series of inward currents of diminishing amplitudes. These responses were reproducible if repeated at intervals of $>80 \mathrm{~s}$. However, if $2 \mathrm{APB}(100 \mu \mathrm{M})$ was added between norepinephrine applications, it blocked the responses (Fig. 7A). After an 80-s wash in normal bath solution, the responses returned, slightly larger than before. The effect of the lower concentration of $10 \mu \mathrm{M} 2 \mathrm{APB}$ was also studied in nine cells where it was found to reduce the norepinephrine-induced current from $-840 \pm 188 \mathrm{pA}$ to $-358 \pm 112 \mathrm{pA}(P<0.05)$. In contrast, $2 \mathrm{APB}(100 \mu \mathrm{M})$ had very little effect on caffeine-evoked $\mathrm{Cl}^{-}$currents (Fig. $7 B$ ). These results are consistent with an action of $2 \mathrm{APB}$ on $\mathrm{IP}_{3}$-sensitive stores, rather than nonspecific actions on either the plasmalemmal $\mathrm{Cl}^{-}$channels or on ryanodine-sensitive stores.

The effect of $2 \mathrm{APB}(100 \mu \mathrm{M})$ on spontaneous activity is shown in Fig. $7 C$. This cell was held at $-40 \mathrm{mV}$ so

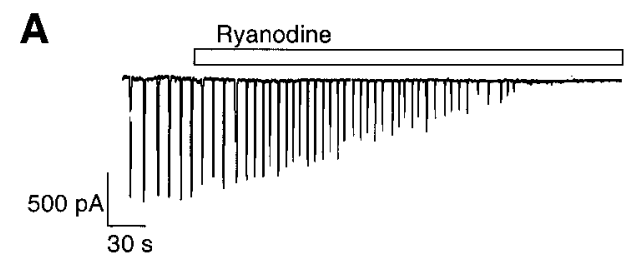

B
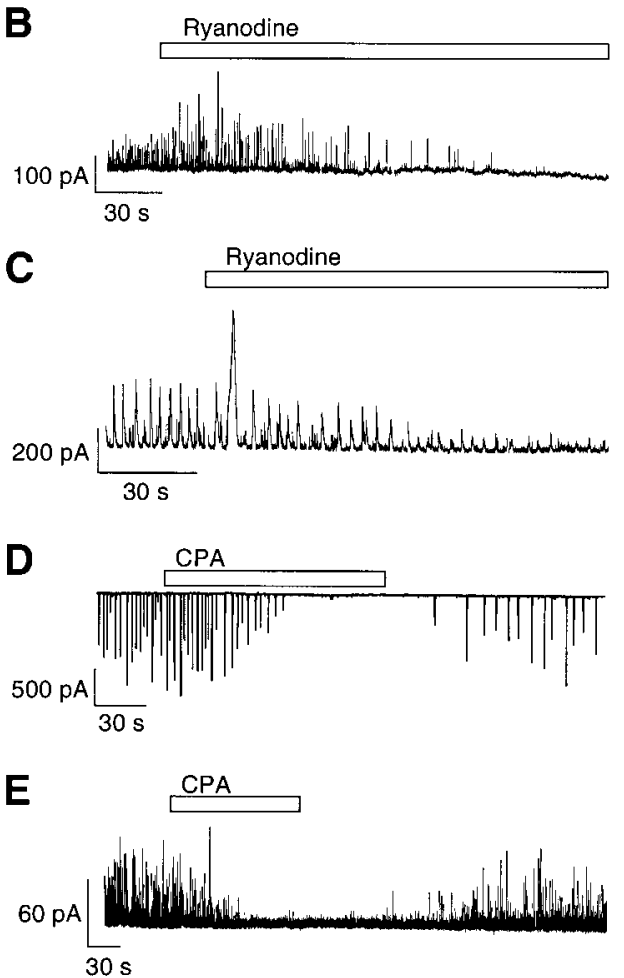

Fig. 5. Depletion of intracellular stores abolishes STICs and STOCS. A: ryanodine $(30 \mu \mathrm{M})$ abolished STICs within $5 \mathrm{~min}$ in a cell held at $-60 \mathrm{mV}\left(\mathrm{Cs}^{+}\right.$pipette, $\left.E_{\mathrm{Cl}}=0 \mathrm{mV}\right) . B$ : ryanodine $(30 \mu \mathrm{M})$ abolished fast STOCs within $5 \mathrm{~min}$ in a cell held at $0 \mathrm{mV}\left(\mathrm{K}^{+}\right.$pipette, $E_{\mathrm{Cl}}=0$ $\mathrm{mV}) . C$ : ryanodine $(30 \mu \mathrm{M})$ also abolished slow STOCs in a different cell under similar conditions. $D$ : cyclopiazonic acid (CPA; $10 \mu \mathrm{M})$ abolished STICs (holding potential $=-60 \mathrm{mV} ; \mathrm{Cs}^{+}$pipette, $E_{\mathrm{Cl}}=0$ $\mathrm{mV})$. $E$ : fast STOCs were also reversibly abolished by $10 \mu \mathrm{M} \mathrm{CPA}$ (holding potential $=0 \mathrm{mV} ; \mathrm{K}^{+}$pipette, $E_{\mathrm{Cl}}=0 \mathrm{mV}$ ). 


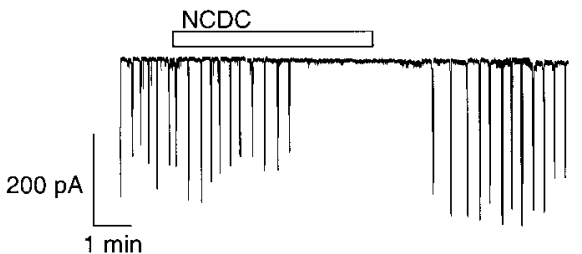

Fig. 6. Inhibition of phospholipase $\mathrm{C}$ abolishes STICs. The trace shows a recording of STICs from a cell held at $-60 \mathrm{mV}$ recorded with $\mathrm{Cs}^{+}$pipette solution. Application of the phospholipase $\mathrm{C}$ blocker 2-nitro-4-carboxyphenyl $N, N$-diphenylcarbamate (NCDC; $100 \mu \mathrm{M}$ ) slowly abolished the STICs. After washout of NCDC, STIC frequency returned to control levels.

that both STICs and STOCs could be studied simultaneously. It can be seen that $2 \mathrm{APB}$ rapidly abolished the STICs while the STOCs remained (although their frequency was reduced by $30 \%$ ). Summary data for the effect of 2APB $(100 \mu \mathrm{M})$ on STICs were obtained in another 13 cells studied at $-60 \mathrm{mV}$ in which it reduced STIC amplitude from $-427 \pm 82 \mathrm{pA}$ to $-14 \pm 9 \mathrm{pA}$, returning to $-431 \pm 81 \mathrm{pA}$ after washout. A lower concentration of $2 \mathrm{APB}(10 \mu \mathrm{M})$ was also effective in blocking STICs, reducing the amplitude from $-542 \pm$ $71 \mathrm{pA}$ to $-75 \pm 49 \mathrm{pA}$ (holding potential $-60 \mathrm{mV}, n=$ $6, P<0.05)$. In four cells in which fast STOCs were studied at $-30 \mathrm{mV}, 2 \mathrm{APB}$ failed to block them but reduced their frequency by $27 \%$ from $122 \pm 17 \mathrm{~min}^{-1}$ to $89 \pm 19 \mathrm{~min}^{-1}(P<0.05)$. When $2 \mathrm{APB}(100 \mu \mathrm{M})$ was studied in cells held at $0 \mathrm{mV}$ to eliminate $\mathrm{Cl}^{-}$currents, its effect was to preferentially block the slow STOCs compared with the fast STOCs. An example is shown in Fig. $8 A$ where, in the control period, slow STOCs can be differentiated from fast STOCs, which occurred either alone or superimposed on the slow STOCs. Exposure to 2APB resulted in abolition of the slow STOCs, while fast STOCs remained. This effect was studied in five cells in which slow STOCs could be readily distinguished from fast STOCs, and, in each case, the slow STOCs were abolished.

Together with the temporal pattern of STOCs and STICs in Fig. 1, the 2APB data suggest that the STICs and slow STOCs are mediated by the same $\mathrm{IP}_{3}$-dependent mechanism, while the fast STOCs are mediated by a different mechanism. This idea was further investigated by examining the effect of nifedipine $(10 \mu \mathrm{M})$ on STICs and STOCs. Figure $8 B$ shows a cell held at $0 \mathrm{mV}$ $\left(E_{\mathrm{Cl}}\right)$ to allow examination of the STOCs without the contaminating effect of the STICs. Addition of nifedipine differentially blocked the fast STOCs, while unmasking a series of slow STOCs that were difficult to distinguish during the control (compare expanded records 1 and 2 in Fig. $8 C$ ). Although the slow STOCs remained, their frequency appeared to be reduced. This trend was observed in a total of four cells in which frequency was reduced by $23 \%$ from $31 \pm 9$ to $24 \pm 3$ $\min ^{-1}$, but this was not statistically significant $(P>$ 0.05). However, nifedipine reduced the frequency of the fast STOCs by $79 \%$ from $11.2 \pm 1.0 \mathrm{~s}^{-1}$ to $2.4 \pm 1.0 \mathrm{~s}^{-1}$ $(n=7, P<0.05)$.

The effect of nifedipine on STICs was examined at potentials of $-60,-40$, and $-20 \mathrm{mV}$ in cells studied with $\mathrm{Cs}^{+}$pipettes to block STOCs. An example is shown in Fig. $9 A$ where it can be seen that as the cell was depolarized to -40 and $-20 \mathrm{mV}$, the frequency of the STICs increased. The cell was then exposed to nifedipine $(10 \mu \mathrm{M})$ and depolarized from -60 to -40
A

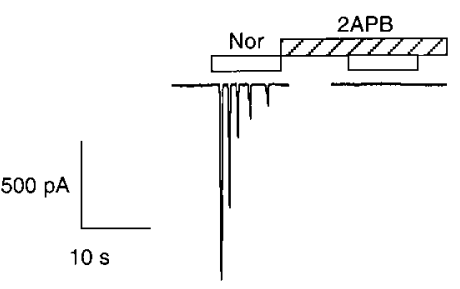

B
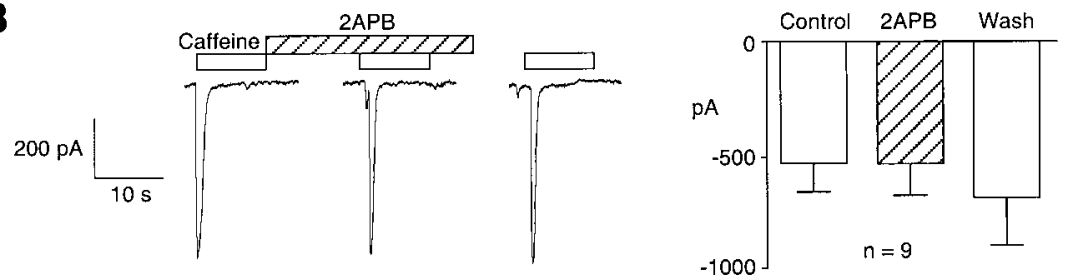

2APB

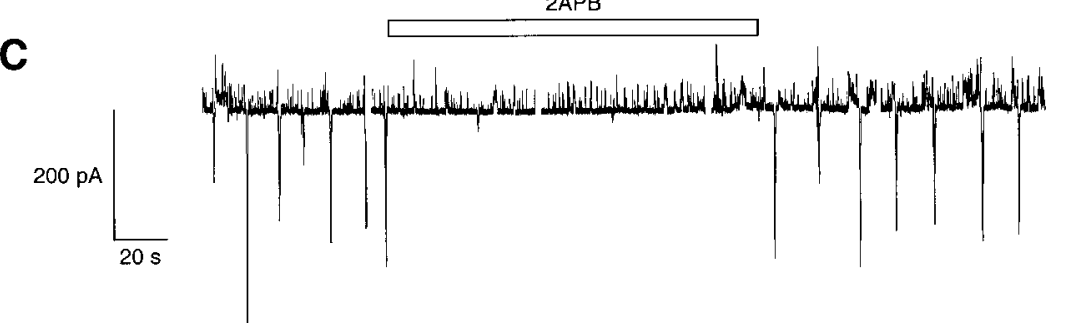

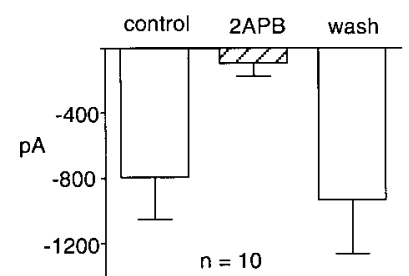

Fig. 7. The effect of 2APB (2-aminoethoxydiphenyl borate; $100 \mu \mathrm{M})$. A: the effect of $2 \mathrm{APB}$ on norepinephrine (Nor)-evoked $\mathrm{Cl}^{-}$currents. $B$ : the effect of the drug on caffeine-evoked $\mathrm{Cl}^{-}$currents. $C: 2 \mathrm{APB}$ blocked the STICs while leaving the fast STOCs. A and $B$ recorded at $-60 \mathrm{mV}$ using $\mathrm{Cs}^{+}$pipettes; $C$ recorded at $-40 \mathrm{mV}$ using a $\mathrm{K}^{+}$pipette. 
Fig. 8. $A$ : records from a cell held at $0 \mathrm{mV}\left(E_{\mathrm{Cl}}\right)$ to allow STOCs to be observed without contamination with $\mathrm{Cl}^{-}$ currents. This cell was firing both fast and slow STOCs. 2APB $(100 \mu \mathrm{M})$ abolished the slow STOCs to clearly unmask the fast STOCs. $B$ : the effect of nifedipine (10 $\mu \mathrm{M})$ in a different cell held at $0 \mathrm{mV}$. Nifedipine had the opposite effect as 2APB, i.e., it unmasked the slow STOCs by reducing the frequency of fast STOCs. $C$ : expanded records corresponding with the periods marked 1 and 2 in $8 B$.

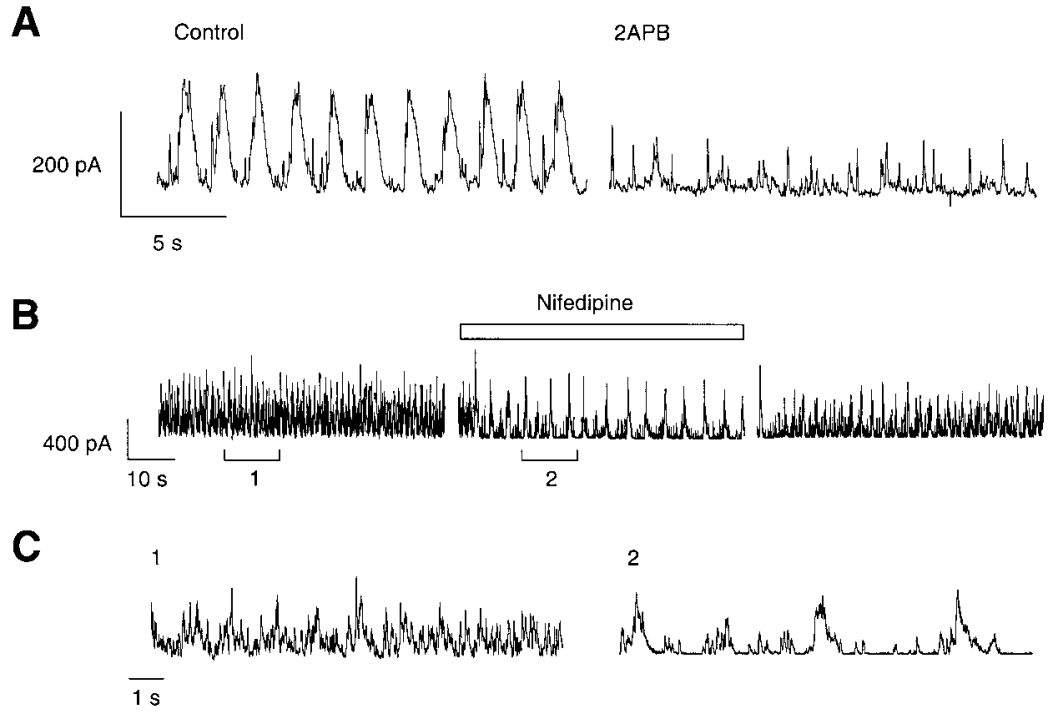

and $-20 \mathrm{mV}$ again. There was little effect of nifedipine at $-60 \mathrm{mV}$, but it reduced the frequency of the STICs at -40 and $-20 \mathrm{mV}$. Summary data from eight cells is shown in Fig. $9 B$ where nifedipine significantly reduced the frequency of STICs at -40 and $-20 \mathrm{mV}$, while having little effect at $-60 \mathrm{mV}$.

\section{DISCUSSION}

In the present study, we have shown that $2 \mathrm{APB}$, an agent recently described as a specific membrane-permeant blocker of $\mathrm{IP}_{3}$-mediated $\mathrm{Ca}^{2+}$ release, blocked STICs in rabbit urethral interstitial cells. Because these cells are prime candidates as the urethral pacemakers (26), our results provide support for the hypothesis that the pacemaker mechanism depends on
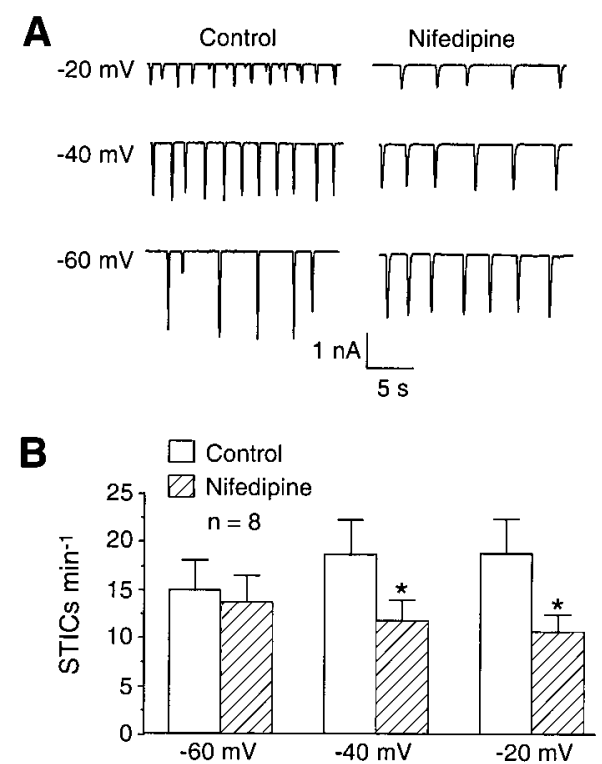

Fig. 9. A: the effect of depolarization on STIC frequency before and after nifedipine $(10 \mu \mathrm{M})$ in a cell studied with a $\mathrm{Cs}^{+}$pipette. $B$ : summary data from 8 similar experiments. Nifedipine had little effect at $-60 \mathrm{mV}$ but significantly reduced the frequency at the other 2 potentials.
$\mathrm{IP}_{3}$-dependent $\mathrm{Ca}^{2+}$ release (see Ref. 10 ). Recent work has also implicated an $\mathrm{IP}_{3}$-dependent pacemaking mechanism in gastric smooth muscle where normal slow wave activity was absent in mutant mice that lacked the type $1 \mathrm{IP}_{3}$ receptor (27) and in mouse jejunum where pacemaking currents in cultured ICC were suppressed by inhibitors of $\mathrm{IP}_{3}$-dependent $\mathrm{Ca}^{2+}$ release (30).

The urethral interstitial cells also fired STOCs that could be differentiated into two types, fast and slow. When recording conditions were set optimally for simultaneous recording of both STICs and STOCs, it was clear that the STICs and slow STOCs were coupled events, implying a shared underlying mechanism, while the fast STOCs occurred independently at a similar fashion to the majority of STOCs widely reported in smooth muscle cells, where they are believed to be activated by localized release of $\mathrm{Ca}^{2+}\left(\mathrm{Ca}^{2+}\right.$ sparks) from ryanodine-sensitive release channels located close to the plasma membrane (for reviews, see Refs. 3 and 14).

Sparks have also been implicated in the activation of STICs in several types of smooth muscle $(8,32)$. Because of the small single-channel conductance of the $\mathrm{Ca}^{2+}$-activated $\mathrm{Cl}^{-}$channels (2.6 pS) (17), it has been estimated that $>600$ of these would have to open to produce an average STIC of approximately $-90 \mathrm{pA}$ in a smooth muscle cell $(14,21)$. Taking into account the $\mathrm{Ca}^{2+}$ sensitivity of the $\mathrm{Cl}^{-}$channels, the total number of $\mathrm{Cl}^{-}$channels per cell $(\sim 10,000)$, and the membrane area $(0.25 \%)$ over which the required $\mathrm{Ca}^{2+}$ concentration is delivered by a spark, it has been estimated that significant clustering of the $\mathrm{Cl}^{-}$channels over the $\mathrm{Ca}^{2+}$ release sites is a prerequisite for sparks to evoke STICs (14). While sparks might be able to evoke the relatively small STIC characteristic of some smooth muscle cells (21), it is unlikely that the much larger STICs described in the present paper could be evoked by single $\mathrm{Ca}^{2+}$ sparks. The STICs in rabbit urethral interstitial faster rate. Indeed, the fast STOCs behaved in a very 
cells often exceeded $-900 \mathrm{pA}$, which would involve activation of around 6,000 channels. This is likely to reflect activation of channels over a much greater area of membrane than could be affected by a single $\mathrm{Ca}^{2+}$ spark. However, it is interesting that in pancreatic acinar cells, large $\mathrm{Cl}^{-}$currents are activated by local $\mathrm{Ca}^{2+}$ events that are confined to the apical membrane $(15,28)$. This appears to depend on a combination of clustering of the $\mathrm{Cl}^{-}$channels on this membrane (31) and close apposition of the endoplasmic reticulum to the membrane maintained by the microtubular network (6). When the latter was disrupted, STICs disappeared, but the response to a supramaximal concentration of carbachol remained. While it is possible that a similar situation exists in urethral interstitial cells, several factors may suggest otherwise. First, these cells resemble smooth muscle cells that do not have well-defined polar membranes like acinar cells. Second, the local $\mathrm{Ca}^{2+}$ events that activate the $\mathrm{Cl}^{-}$currents in acinar cells are still very large compared with the sparks seen in smooth muscle.

The situation in urethral interstitial cells may more closely resemble that in rat portal vein myocytes, where sparks were observed to activate STOCs, but $\mathrm{Ca}^{2+}$-activated $\mathrm{Cl}^{-}$currents were only observed during a propagating $\mathrm{Ca}^{2+}$ wave (evoked by $10 \mathrm{mM}$ caffeine) (24). Propagating waves in smooth muscle are also evoked by agonists that are coupled to $\mathrm{IP}_{3}$ as the second messenger $(2,8)$ and may occur spontaneously in a variety of cells where there is basal $\mathrm{IP}_{3}$ production (9). It is possible, therefore, that the STICs in urethral interstitial cells are generated by $\mathrm{Ca}^{2+}$ waves in response to spontaneous production of $\mathrm{IP}_{3}$. In support of this argument, NCDC, a phospholipase C inhibitor, and xestospongin $\mathrm{C}$ and $2 \mathrm{APB}$, both of which have been reported to block the action of $\mathrm{IP}_{3}(7,23)$, abolished the STICs. Because xestospongin $\mathrm{C}$ has been reported to have certain nonspecific actions, including causing $\mathrm{Ca}^{2+}$ release (4) and blockade of the sarcoplasmic $\mathrm{Ca}^{2+}$ pump (5), we concentrated the most effort on the action of $2 \mathrm{APB}$. This drug was first shown to inhibit $\mathrm{IP}_{3}$ mediated $\mathrm{Ca}^{2+}$ release in rat cerebellar microsomes and human platelets where it appeared to inhibit opening of the channel domain of the $\mathrm{IP}_{3}$ receptor without affecting either $\mathrm{IP}_{3}$ binding or $\mathrm{IP}_{3}$ production (23). This action seemed to be specific as it failed to block caffeine-induced $\mathrm{Ca}^{2+}$ release from cardiac and skeletal sarcoplasmic reticulum vesicles (23). It also blocked agonist-induced contractions in both rabbit aorta (23) and rat myometrium (1) over the concentration range of $10-100 \mu \mathrm{M}$. In high concentrations (generally $>200$ $\mu \mathrm{M})$, it developed some tendency to cause $\mathrm{Ca}^{2+}$ release and to block $\mathrm{Ca}^{2+}$ uptake into stores (23). The concentrations used in the present study did not induce inward or outward currents, suggesting that it was unlikely to have caused significant $\mathrm{Ca}^{2+}$ release. It was also unlikely to have blocked $\mathrm{Ca}^{2+}$ uptake, because we found that it had no effect on caffeine response, although it blocked norepinephrine-induced $\mathrm{Cl}^{-}$currents. Also, although it blocked STICs, it only slightly reduced the frequency of fast STOCs. Again, this sug- gests that its effect was unlikely to have been due to blockade of $\mathrm{Ca}^{2+}$ uptake since the $\mathrm{Ca}^{2+}$-ATPase blocker CPA abolished STOCs.

Several complicating factors, however, remain to be explained. First, 2APB produced a $30 \%$ reduction in the frequency of fast STOCs, and second, ryanodine blocked all of the responses. The first observation may be explained by the fact that $\mathrm{IP}_{3}$ has been shown to increase spark frequency in vascular myocytes (8). This probably arises because the $\mathrm{Ca}^{2+}$ released from the $\mathrm{IP}_{3}$-sensitive store causes $\mathrm{Ca}^{2+}$ release from the ryanodine-sensitive store by $\mathrm{Ca}^{2+}$ induced-Ca ${ }^{2+}$ release (CICR). Indeed, there have been several studies (16, 19) in which heparin or xestospongin $C$ reduced STOC frequency in smooth muscle cells, suggesting that $\mathrm{IP}_{3}$ may modulate these currents. Interaction between $\mathrm{IP}_{3^{-}}$ and ryanodine-sensitive stores also helps to explain the second observation, since it has been demonstrated that CICR at the ryanodine receptor is a requirement for the propagation of an $\mathrm{IP}_{3}$-induced $\mathrm{Ca}^{2+}$ wave (2). Thus norepinephrine-induced $\mathrm{Ca}^{2+}$ waves were abolished if either the $\mathrm{IP}_{3^{-}}$or ryanodine-sensitive channels were blocked (2). This result could explain how ryanodine blocked the STICs in the present study, even though the $\mathrm{IP}_{3}$-sensitive store was the driver of the pacemaking mechanism.

Finally, it is interesting to speculate the functional significance of STICs and STOCs in the rabbit urethral interstitial cells. We propose that $\mathrm{IP}_{3}$-dependent $\mathrm{Ca}^{2+}$ waves initiate the STICs and slow the STOCs in these cells. At potentials below $-40 \mathrm{mV}$, the $\mathrm{Cl}^{-}$-mediated STICs predominate over the slow STOCs, probably because at these potentials the voltage- and $\mathrm{Ca}^{2+}$ sensitive properties of the BK channel determine that open probability is low (see Refs. 8 and 32). This would allow the cell to fire STDs from the resting potential under physiological conditions. However, the cell can still fire fast STOCs at potentials as negative as -50 $\mathrm{mV}$. These would arise if BK channels were activated in areas of plasma membrane overlying the ryanodinesensitive release channels that discharge localized sparks of extremely high $\mathrm{Ca}^{2+}$ concentrations (14), but we speculate that a lack of clustering of $\mathrm{Cl}^{-}$channels in these regions means that very little $\mathrm{Cl}^{-}$current is activated concurrently. In this case, the activation of BK channels by sparks is allowed to go unchecked, generating a net outward current. This opens up the intriguing possibility that fast STOCs set the membrane potential in interstitial cells, similar to their proposed action in arterial smooth muscle cells (14), whereas large STICs are responsible for the generation of rhythmic depolarizations. Such a subtle mechanism could explain how two $\mathrm{Ca}^{2+}$-sensitive channels, which produce opposite effects on membrane potential, could be independently regulated by different $\mathrm{Ca}^{2+}$-release events to determine the overall electrical activity of the pacemaker cells. However, these ideas must remain speculative until further studies characterize the $\mathrm{Ca}^{2+}$ events that underlie STICs and STOCs in these cells and until the anatomical relationship among the $\mathrm{Cl}^{-}$ 
channels, the $\mathrm{BK}$ channels, and the $\mathrm{Ca}^{2+}$ stores is defined.

We thank the European Union and the Queen's University Faculty of Medicine for providing financial support. G. P. Sergeant was supported by a European Social Fund scholarship.

\section{REFERENCES}

1. Ascher-Landsberg J, Saunders T, Elovitz M, and Phillippe M. The effects of 2-aminoethoxydiphenyl borate, a novel inositol 1,4,5-trisphosphate receptor modulator on myometrial contractions. Biochem Biophys Res Commun 264: 979-982, 1999.

2. Boittin FX, Macrez N, Halet G, and Mironneau J. Norepinephrine-induced $\mathrm{Ca}^{2+}$ waves depend on $\mathrm{InsP}_{3}$ and ryanodine receptor activation in vascular myocytes. Am J Physiol Cell Physiol 277: C139-C151, 1999.

3. Bolton TB and Imaizumi Y. Spontaneous transient outward currents in smooth muscle cells. Cell Calcium 20: 141-152, 1996.

4. Broad LM, Cannon TR, and Taylor CW. A noncapacitative pathway activated by arachidonic acid is the major $\mathrm{Ca}^{2+}$ entry mechanism in rat A7r5 smooth muscle cells stimulated with low concentrations of vasopressin. J Physiol (Lond) 517: 121-134, 1999.

5. DeSmet P, Parys JB, Callewaert G, Weidema AF, Hill E, DeSmedt H, Erneux C, Sorrentino V, and Missiaen L. Xestospongin $\mathrm{C}$ is an equally potent inhibitor of the inositol 1,4,5-trisphosphate receptor and the endoplasmic reticulum $\mathrm{Ca}^{2+}$ pumps. Cell Calcium 26: 9-13, 1999.

6. Fogarty KE, Kidd JF, Turner A, Skepper JN, Carmichael J, and Thorn P. Microtubules regulate local $\mathrm{Ca}^{2+}$ spiking in secretory epithelial cells. J Biol Chem 275: 22487-22494, 2000.

7. Gafni J, Munsch JA, and Lam TH. Xestospongins: potent membrane permeable blockers of inositol 1,4,5-trisphosphate receptor. Neuron 19: 723-733, 1997.

8. Gordienko DV, Zholos AV, and Bolton TB. Membrane ion channels as physiological targets for local $\mathrm{Ca}^{2+}$ signalling. $J$ Microsc 196: 305-316, 1999.

9. Hajnoczky G and Thomas AP. Minimal requirements for calcium oscillations driven by the $\mathrm{IP}_{3}$ receptor. EMBO $J 16$ : 3533-3543, 1997.

10. Hashitani $\mathbf{H}$ and Edwards FR. Spontaneous and neurally activated depolarizations in smooth muscle cells of the guineapig urethra. J Physiol (Lond) 514: 459-470, 1999.

11. Hashitani H, Van Helden DF, and Suzuki H. Properties of depolarizations in circular smooth muscle cells of rabbit urethra. Br J Pharmacol 118: 1627-1632, 1996.

12. Hollywood MA, McCloskey KD, McHale NG, and Thornbury KD. Characterization of outward $\mathrm{K}^{+}$currents in isolated smooth muscle cells from sheep urethra. Am J Physiol Cell Physiol 279: C420-C428, 2000.

13. Horowitz B, Ward SM, and Sanders KM. Cellular and molecular basis for electrical rhythmicity in gastrointestinal muscles. Annu Rev Physiol 61: 19-43, 1999.

14. Jaggar J, Porter V, Lederer WJ, and Nelson MT. Calcium sparks in smooth muscle. Am J Physiol Cell Physiol 278: C235C256, 2000

15. Kasai H, Li YX, and Miyashita Y. Subcellular distribution of $\mathrm{Ca}^{2+}$ release channels underlying $\mathrm{Ca}^{2+}$ waves and oscillations in exocrine pancreas. Cell 74: 669-677, 1993.

16. Kitamura $\mathbf{K}$, Xiong $\mathbf{Z}$, Teramoto $\mathbf{N}$, and Kuriyama $\mathbf{H}$. Roles of inositol trisphosphate and protein kinase $\mathrm{C}$ in the spontaneous outward current modulated by calcium release in rabbit portal vein. Pflügers Arch 421: 539-551, 1992.
17. Klockner U. Intracellular calcium ions activate a low-conductance chloride channel in smooth muscle cells isolated from human mesenteric artery. Pflügers Arch 424: 231-237, 1993.

18. Knaus HG, McManus OB, Lee SH, Schmalhofer WA, Garcia-Calvo M, Helms LMH, Sanchez M, Giangiacomo K, Reuben JP, Smith AB, Kaczorowski GJ, and Garcia ML. Tremorgenic indole alkaloids potently inhibit smooth muscle high-conductance calcium-activated potassium channels. Biochemistry 33: 5819-5828, 1994.

19. Kong ID, Koh SD, and Sanders KM. Purinergic activation of spontaneous transient outward currents in guinea pig taenia colonic myocytes. Am J Physiol Cell Physiol 278: C352-C362, 2000 .

20. Langton P, Ward SM, Carl A, Norell MA, and Sanders KM. Spontaneous electrical activity of interstitial cells of Cajal isolated from canine proximal colon. Proc Natl Acad Sci USA 86: 7280-7284, 1989.

21. Large W and Wang Q. Characteristics and physiological role of the $\mathrm{Ca}^{2+}$-activated $\mathrm{Cl}^{-}$conductance in smooth muscle. Am $J$ Physiol Cell Physiol 271: C435-C454, 1996.

22. Liu WC, Thuneberg L, and Huizinga J. Cyclopiazonic acid, inhibiting the endoplasmic reticulum calcium pump, reduces the canine colonic pacemaker frequency. J Pharmacol Exp Ther 275: 1058-1068, 1995.

23. Maruyama T, Kanaji T, Nakade S, Kanno T, and Mikoshiba K. 2APB, 2-aminoethoxydiphenyl borate, a membranepenetrable modulator of $\operatorname{Ins}(1,4,5) \mathrm{P}_{3}$-induced $\mathrm{Ca}^{2+}$ release. J Biochem (Tokyo) 122: 498-505, 1997.

24. Mironneau J, Arnaudeau S, Macrez-Lepretre N, and Boittin FX. $\mathrm{Ca}^{2+}$ sparks and $\mathrm{Ca}^{2+}$ waves activate different $\mathrm{Ca}^{2+}$ dependent ion channels in single myocytes from rat portal vein. Cell Calcium 20: 153-160, 1996.

25. Rae J, Cooper K, Gates $\mathbf{P}$, and Watsky M. Low access resistance perforated patch recordings using amphotericin B. J Neurosci Methods 37: 5-26, 1991.

26. Sergeant GP, Hollywood MA, McCloskey KD, Thornbury KD, and McHale NG. Specialised pacemaking cells in the rabbit urethra. J Physiol (Lond) 526: 359-366, 2000

27. Suzuki H, Takano H, Yamamoto Y, Komuro T, Sato M, Kato H, and Mikoshiba K. Properties of gastric smooth muscle obtained from mice which lack inositol trisphosphate receptor. J Physiol (Lond) 525: 105-111, 2000.

28. Thorn P, Lawrie AM, Smith PM, Gallacher DV, and Petersen $\mathrm{OH}$. Local and global cytosolic $\mathrm{Ca}^{2+}$ oscillations in exocrine cells evoked by agonists and inositol trisphosphate. Cell 74: $661-668,1993$

29. Van Helden DF, Imtiaz MS, Nurgaliyeva K, von der Weid, and Dosen PJ. Role of $\mathrm{Ca}^{2+}$ stores and membrane voltage in the generation of slow wave action potentials in guinea pig gastric pylorus. J Physiol (Lond) 524: 245-265, 2000.

30. Ward SM, Ordog T, Koh SD, Abu Baker S, Jun JY, Amberg G, Monaghan K, and Sanders KM. Pacemaking in interstitial cells of Cajal depends upon calcium handling by endoplasmic reticulum and mitochondria. J Physiol (Lond) 525: 355-361, 2000

31. Zdebik A, Hug MJ, and Gregor R. Chloride channels in the luminal membrane of rat pancreatic acini. Pflügers Arch 434: 188-194, 1997.

32. ZhuGe R, Sims SM, Tuft RA, Fogarty KE, and Walsh JV. $\mathrm{Ca}^{2+}$ sparks activate $\mathrm{K}^{+}$and $\mathrm{Cl}^{-}$channels, resulting in spontaneous transient currents in guinea-pig tracheal myocytes. J Physiol (Lond) 513: 711-718, 1998. 